\title{
Business Trust and Communication as Predictors of Business Growth
}

\author{
STAVROS KALOGIANNIDIS \\ Department of Business Administration, \\ University of Western Macedonia, \\ GREECE \\ ORCiD: https://orcid.org/0000-0002-2337-5775
}

\begin{abstract}
Increased globalization and competition in most industries has greatly changed the execution of different duties and responsibilities most especially the flow of communication in businesses. This has further affected the level of trust in most businesses most especially among the employees and between the business and customers. The main objective of the study was to investigate the effect if business communication and business trust on business growth. Data was collected using an online survey questionnaire from 100 employees of Intrasoft International in Greece. Data collected was analyzed using SPSS and Pearson's rank correlation coefficient was based on to establish the relationship between variables. The level top which the independent variables predict the dependent variables was established using regression analysis. The study established a positive relationship between business communication and business. A significant and positive relationship was also confirmed between business trust and business growth.
\end{abstract}

Key-words: - Business communication, Business Trust, Business Growth

Received: March 15, 2021. Revised: November 8, 2021. Accepted: November 18, 2021. Published: December 2, 2021.

\section{Background to the Study}

Business communication can be defined as a process where both employers and employees of a business organization share information not only among themselves but also outside the business environment (Kalogiannidis, 2020). Communication is a critical aspect in business as important information pertaining the business organization is passed from the employers to the employees.it is through communication that managers assign tasks to the employees. It is also through communication that the employees channel their complaints to the management. Customers can also know any changes within the business through communication. Therefore, effective communication is an important factor as far as business growth is concerned(Kalogiannidis \& Papaevangelou, 2020). Many businesses have failed to achieve the set goals and objectives simply because of these two aspects(Godlovitch et al., 2013). There are no proper measures put in place in order to enhance effective communication both within and without the business. Furthermore, trust issues have also recently emerged hence posing greater risks to business owners. Yung (2018) indicates that effective communication ensures that information is passed from one party to the other as within the shortest time possible. Kalogiannidis (2020) indicates that lack of effective communication can lead to business failure. For instance, it is through communication that the manager tasks the employees. If there is no effective communication, employees might not complete the required tasks in due time. This may lead to loss of customers who shall be kept waiting for services being offered by the business(Zeffane et al., 2011). The business also needs effective communication with its customers. This is because customers are the sole providers for any business hence should be promptly informed on any changes pertaining terms of services of the business or any other customer related issue(Takemura \& Sulimowska-formowicz, 2019). This helps to increase trust and loyalty towards the services offered by the company thereby lading to business growth(Mohd, 2012).

\subsection{Problem Statement}

Increased globalization and competition in most industries has greatly changed the execution of different duties and responsibilities. Most businesses are failing to achieve higher productivity or profitability due to the challenges caused by 
globalization (Kalogiannidis \& Papaevangelou, 2020). For example the channels of communication used in businesses have greatly changed in the modern world and this has consequently affected the level of trust earned from customers and between employees and their employers (Takemura \& Sulimowska-formowicz, 2019). The main objective of any business is to earn income which is the profit by providing goods and services to customers who receive them in exchange of money. Profit can only be realized if the trustee is loyal to the beneficiaries. For instance, in a scenario where the trustee is not loyal, issues relating to fraud and theft will emerge. If such happens then the business owners is bound to suffer loses and thus the business may fail(Yung, 2018). There is study limited research on the combined effect of business trust and communication on the growth of businesses. Therefore, this study sought to investigate the effect of business communication and business trust on business growth.

\section{Objectives of the study}

I. To explore the relationship between effective business communication and business growth.

II. To establish the relationship between business trust and business growth.

\section{Research hypotheses}

I. There is a significant relationship between effective business communication and business growth.

II. There is a significant relationship between business trust and business growth.

\subsection{Significance}

This study contributes to the existing theoretical and empirical knowledge concerning the general effect of business trust and business communication on the growth of business.

\section{Literature Review}

This section reviews the theoretical and empirical perspectives of the study

\subsection{Theoretical Review}

Most communication scholars have continued to communicate and, as a result, incorporate business communication at various levels of study, ranging from micro to macro organizational levels (Mouzas et al., 2007; Prochaska \& Velicer, 1997). The social cognitive theory of Albert Bandura (1999) and the transtheoretical model of Prochaska \& Velicer (1997) argue that an individual's general behavior is often shaped by the viewpoints of the larger society and social environment. As a consequence, initiatives aimed at maintaining efficient communication in the workplace should always involve any measures that affect positive improvements in the broader organizational environment.

Similarly, most persuasion research has centered on how individual-level contact affects a person's overall actions. Most researchers have attempted to explain why most organizations continue to change, particularly as they are currently developed and transformed by various interactions among various groups and systems(Godlovitch et al., 2013; Waylen, 2017). In most cases, the most critical experiences that contribute to meaningful organizational change take place among members of the organization.

The majority of the early research focused on employee behavior changes as a result of inadequate communication in the workplace. Most of these studies showed that a number of factors influenced behavioral change, including the reliability of the evidence or knowledge source, anxiety, the essence of claims, and personality differences, among others(Kalogiannidis \& Papaevangelou, 2020; Prochaska \& Velicer, 1997). Most business studies have stressed cognitive analysis of data or knowledge that contributes to persuasion since the 1960 s(Yung, 2018). Recent studies, on the other hand, have revealed that business trust and controlled communication is a critical and strategic tool for businesses to achieve their desired profitability and performance development (Mohd Yusuf, 2012; Takemura \& Sulimowska-formowicz, 2019).

\subsection{Empirical Review}

\subsubsection{Effective Communication in a Business Organization}

Effective communication can be achieved by avoiding use of expensive methods of communication such as email (Sinha, 2012). This is because information can only be accessed when one has a proper internet connection which is not affordable to everyone. Therefore, information should be passed orally when for affordability purpose. In addition to that, oral conversation is 
efficient as one can ask a question where he or she does not understand and the instructor can respond to it as quick as possible. In this case, while giving tasks to employees, the manager should ensure he or she uses oral communication(Godlovitch et al., 2013). Another way is to avoid use of abusive language while communicating. For proper understanding between parties, a good and polite language must be used. It is therefore important for the manager to handle employees with respect when giving out tasks to be completed. This ensures that the business achieves its set goals and objectives. According to Waylen (2017), simple and clear language should be used for easier understanding. This helps to prevent confusion as everyone will interpret information in a correct manner. Customers are also be able to understand any changes pertaining goods and services clearly and easily. Moreover, to enhance effective communication, the message should also be accompanied by various non-verbal aspects such as gestures in order to make the receiver understand more. This can be applied when the supervisor is giving out instructions to the employees(Radomska et al., 2019).

\subsubsection{Importance of Effective Communication in a Business}

Several research carried out by scholars suggest that effective communication is key as far as business growth is concerned. According to (McLean, 2013), effective communication is important enables employees to be well informed and motivated about tasks to be done which are normally assigned by managers or supervisors. In addition to that, the managers can not only clearly demonstrate to employees how tasks are supposed to be done but also help them improve their performance. This enhances productivity both in terms of quantity and quality and enables the company to improve on its sales thus maximizing profit. Communication is also applicable in the decision making process(Kalogiannidis, 2020). Here, people exchange ideas hence analyzing various alternatives in order to come up with a rational informed solution. This means that it is only through effective communication that an organization can come up with an informed decision concerning the business. Decision making provides a platform for consultations and consensus. Informed decisions are important as they eventually make the business grow. Problems faced by the business are normally solved through the decision making criteria(Godlovitch et al., 2013). Furthermore, effective communication enhances team work within the organization. If everyone within the organization is well informed, there shall be team work and togetherness as all employees shall be committed to work towards a common goal(Godlovitch et al., 2013). Team work eventually leads to success as employees would help each other improve his or her skills. This enhances productivity and by doing so the business achieves strategic growth. Effective communication assists in the controlling process. The management is able to control the behavior of other organizational members. In any business organization, there are fundamental principles normally set aside by the management used to guide and control everyone's behavior. Through effective communication, all members in the organization understand and strictly abide by the rules(Hakanen et al., 2016).

\subsubsection{Business Trust as Growth Predictors}

Most researchers have found out that trust is a core value in a business. There should be trust between the business and its customers, suppliers and vendors. This trust is what binds the parties together(Kalogiannidis, 2020). Trust gives a chance for every party to play its role as required. If there is trust between the business and its suppliers, the suppliers would be comfortable in delivering inventory as they have an assurance of getting paid. However, if the business is not honest with their suppliers, the suppliers may run away from risks that may occur due to lack of payment by the business. The business will therefore lose their suppliers and in the longrun productivity will be affected. The business will not achieve its set goals(Mouzas et al., 2007).

The same concept applies to customers who are the sole providers of the business. Trust must exist between these two parties for efficient running of the business. Incase there is no trust, customers will not buy the products thus the business may end up receiving loses(Zeffane et al., 2011). On the other hand, if trust exists then customers will be comfortable buying goods or services being provided by the business in exchange of their money(Mohd Yusuf, 2012). In addition to that, it is because of trust that a business can acquire financial assistance from financial institutions. It is also because of trust that a business can acquire inventory inform of credit. In 
conclusion, it is evident that trust must be there for a business to run and achieve its goals(Yung, 2018).

\subsubsection{External and Internal Communication}

Effective communication involves both external and internal communication. External communication is that which information is transferred from the organization to an external party. For instance, a business can convey information to its customers and suppliers. This type of information should also be effective in order for the business to grow and achieve its set goals and objectives(Hakanen et al.,
2016). Internal communication is that which information is shared within the organization. For example, the manager can assign tasks and give out specific instructions to the employees, the manager can also inform shareholders on how the business is going on and many more. Internal communication also influences the growth of a business because it enhances coordination and unity in carrying out activities. By doing so, the business can achieve its goals and objectives(Kalogiannidis \& Papaevangelou, 2020). Communication can be summarized in the following steps.
ENCORDER

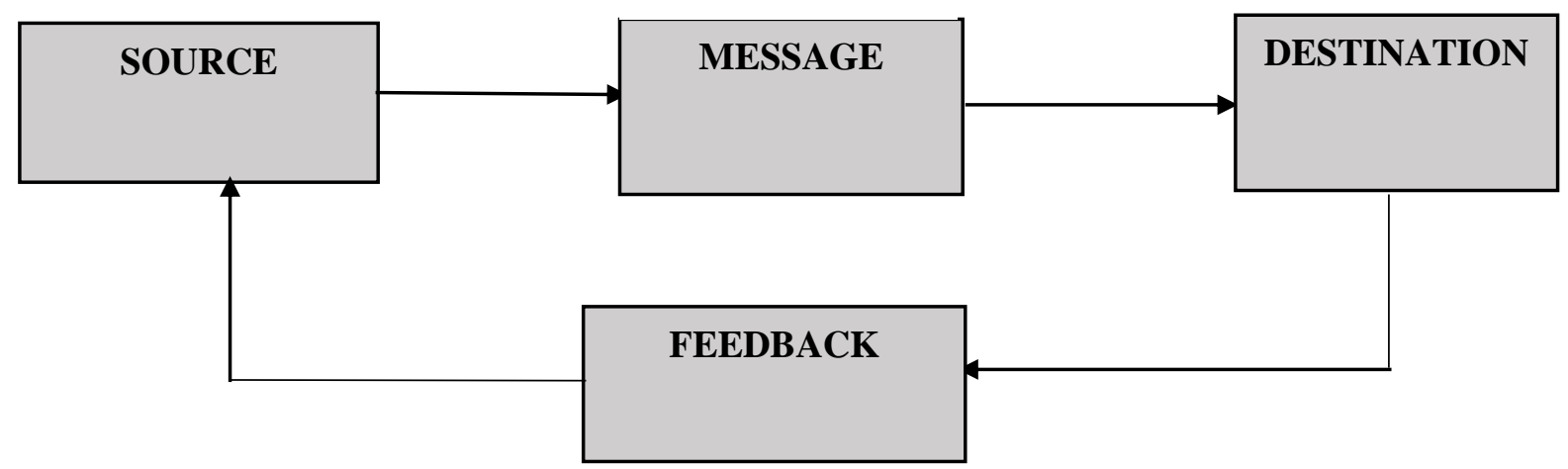

Fig. 1: Flow of communication in a company

\subsubsection{Business Growth}

Scholars define business growth as a situation where a business experiences an increase in its revenue in terms of profitability and on the other hand decreasing its operational costs. In addition to that, growth also refers to the general expansion of a business enterprise in terms of assets, human resource, quantity of goods produced and market coverage. However, business trust is a set up where the properties and assets of a business organization are channeled and entrusted to a specific trustee whose role is to manage all operations for beneficiaries' profit. This means that the trustee does not work for his own profit but for the profit of the beneficiaries who are the real owners or investors of the business. There should therefore be trustworthiness between the beneficiaries and the trustee for the purpose of credibility and loyalty(Mohd Yusuf, 2012).

\section{Methodology}

This section describes the different methods and tool used in the study

\subsection{Research Design}

The research adopted a descriptive survey design which enables exploration and analysis of the relationship that exists between business communication, business trust and general growth of a business.

\subsection{Sample Size}

Participants of the survey were 100 employees of a personal computers and desk tops manufacturing company known as Intrasoft International in Greece, which is an ever growing company in terms of profit, market coverage and the number of employees. This company was chosen in order to find out the relationship between growth and communications and business trust.

\subsection{Sampling Technique}

Probability sampling technique was employed throughout the study whereby simple random sampling was used as a method of participant selection. 


\subsection{Data Collection}

Data collection was conducted through online survey questionnaire from the selected participants by observing different ethical requirements such as obtaining informed consent from the study participants. The questions contained on the questionnaire focused on establishing the opinions of respondents concerning the level to which business trust and communication have influenced growth in their company. A Likert scale of 1-5 representing; Strongly disagree (1), disagree (2), Undecided (3), agree (4), and strongly agree (5), was based on to measure the dependent and independent variables.

\subsection{Data Analysis}

Data collected was carefully codded and consequently analyzed using SPSS. Results were presented in form of tables and graphs and consequently interpreted based on frequencies and percentages. Correlation analysis was considered to establish the relationship between the study variables. Regression analysis was also conducted to establish the level to which the dependent variable is predicated by the different independent variables (business communication and business trust). The model that was used in regression analysis is presented below;
Where;

$\mathrm{Y}=$ Business growth

$\beta 0=$ constant $($ coefficient of intercept);

$X_{1}=$ Business communication,

$X_{2}=$ Business trust

$\varepsilon=$ Represents the error term in the multiple regression model

$\beta 1 \ldots \beta 3=$ Represents the regression coefficient of the two independent variables which helped to determine the level of influence that the independent variables on the dependent variable.

\section{Results}

This section presents the different results obtained after data analysis and these helped in meeting the different objectives of the study.

\subsection{Demographic Characteristics}

Of the 100 employees of the computer company, $56 \%$ were male and only $44 \%$ were female as presented in Figure 2.

\section{$Y=\beta_{o}+\beta_{1} X_{1}+\beta_{2} X_{2}+\varepsilon \ldots \ldots \ldots . . . . .3 .1$}

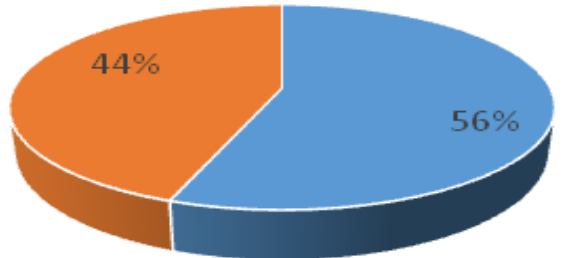

- Male

- female

Fig. 2: Percentage distribution of respondents by gender

Source: Survey (2021)

In terms of respondent age distribution, the study found out that the highest proportion of respondents $(46.7 \%)$ were in the category of $21-40$ years and those in the category of less than 20 years $(8.9 \%)$ as presented in figure 3 . 


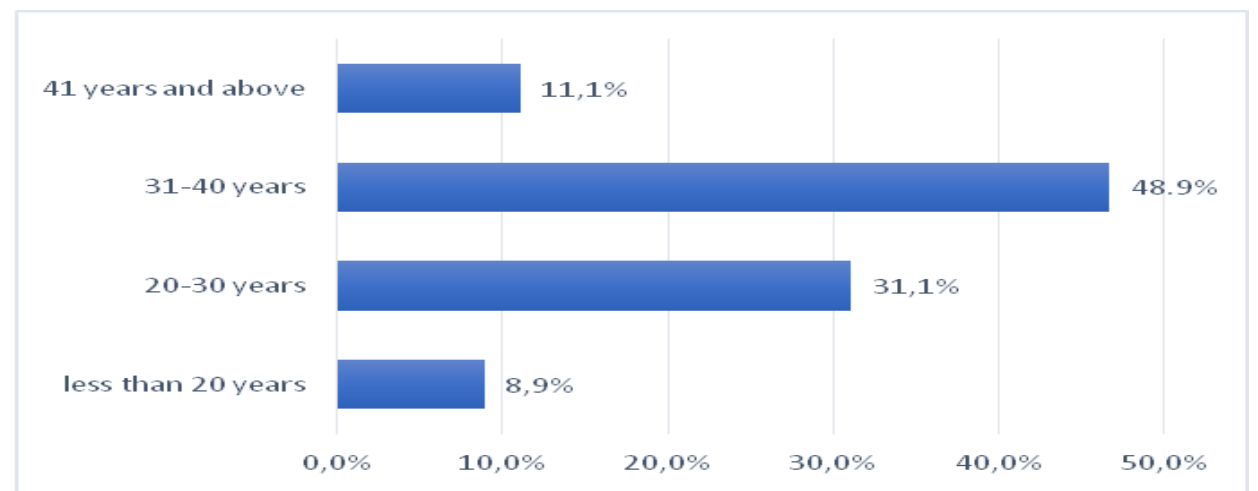

Fig. 3: Age bracket of the respondents Source: Survey (2021)

Respondents were also asked about the number of years they had spent working in the computer company and more than half of the respondents (57.4\%) had spent $2-5$ years, $24.6 \%$ had spent 5 years and above, $11.1 \%$ had spent $1-2$ years, while the least number of respondents $(6.9 \%)$ were less than one year as employees of the company.

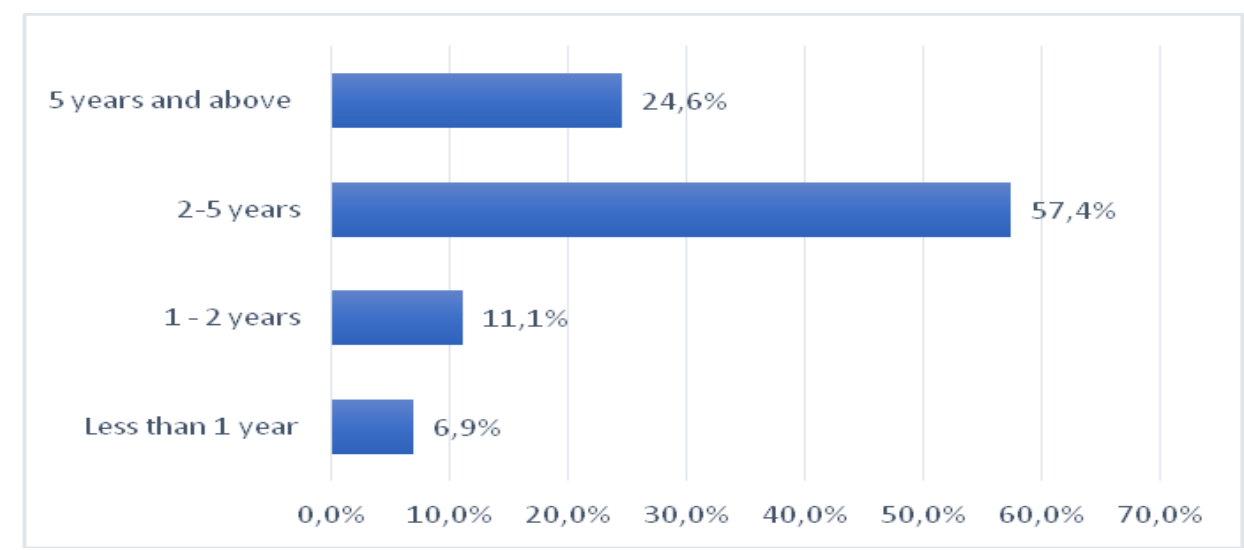

Fig. 4: Years sent working with the company

Source: Survey (2021)

Majority of the respondents (95\%) also indicated that communication and trust in the business and only 5\% there been any improvement in terms of were not in agreement with this notion as presented in figure 5

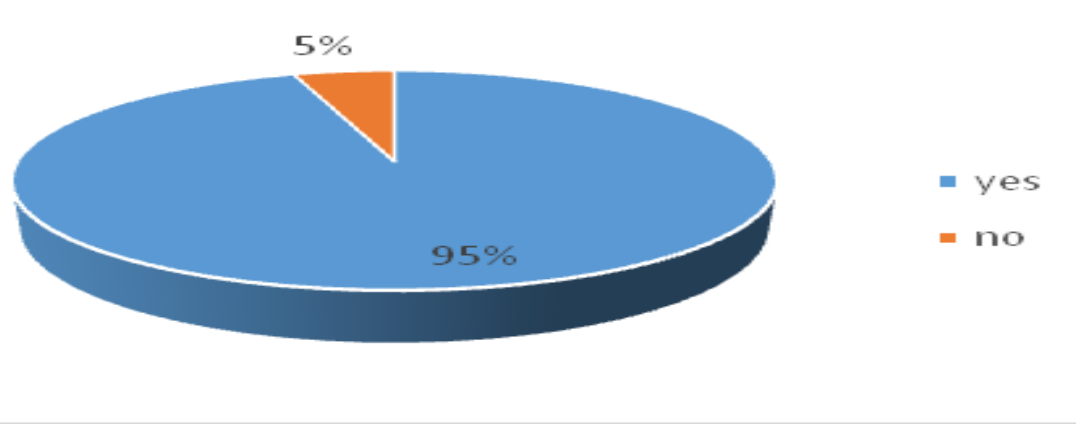

Fig. 5: Improvement in terms of communication and trust in the business

Source: Survey (2021) 


\subsection{Descriptive Statistics on Effective Business Communication}

Table 1. Showing descriptive statistics on effective business communication

\begin{tabular}{|c|c|c|c|c|c|c|}
\hline \multirow{3}{*}{$\begin{array}{l}\text { Statement } \\
\text { Horizontal communication influences proper } \\
\text { decision making in a business }\end{array}$} & & 1 & 2 & 3 & 4 & 5 \\
\hline & Frequency & 6 & 8 & 11 & 44 & 21 \\
\hline & $\%$ & 6.7 & 8.9 & 12.2 & 48.9 & 23.3 \\
\hline \multirow{2}{*}{$\begin{array}{l}\text { Business negotiations are successful through } \\
\text { proper communication with clients }\end{array}$} & Frec & 9 & 13 & 10 & 41 & 17 \\
\hline & $\%$ & 10.0 & 14.4 & 11.1 & 45.6 & 18.9 \\
\hline \multirow{2}{*}{$\begin{array}{l}\text { Communication enhances customer relationship } \\
\text { management }\end{array}$} & Frequency & 5 & 11 & 7 & 36 & 31 \\
\hline & $\%$ & 5.6 & 12.2 & 7.8 & 40.0 & 34.4 \\
\hline \multirow{2}{*}{$\begin{array}{l}\text { Downward communication boosts relationship } \\
\text { between employers and the staff }\end{array}$} & Freq & 8 & 6 & 11 & 44 & 21 \\
\hline & $\%$ & 8.9 & 6.7 & 12.2 & 48.9 & 23.3 \\
\hline \multirow{2}{*}{$\begin{array}{l}\text { Managerial efficiency is possible through } \\
\text { effective communication }\end{array}$} & Frequency & 18 & 30 & 11 & 22 & 9 \\
\hline & $\%$ & 20.0 & 33.3 & 12.2 & 24.4 & 10.0 \\
\hline
\end{tabular}

Source: Survey (2021)

Results from table 1 show that majority of respondents (48.9\%) agreed that horizontal communication influences proper decision making in a business and only $8.9 \%$ disagreed. Concerning whether business negotiations are successful through proper communication with clients, majority of the participants $(45.6 \%)$ agreed while only $10.0 \%$ strongly disagreed. This was an indication that effective or proper communication flow encourages successful negotiations in businesses. In regard to whether communication enhances customer relationship management, majority of respondents (40\%) agreed while only 5.6\% strongly disagreed.
With respect to whether downward communication boosts relationship between employers and the staff, majority of the respondents $(48.9 \%)$ and only $6.7 \%$ disagreed. The result confirms the fact that communication from the top management to the lower level employees influences higher productivity which translates unto higher profitability and business growth on the longrun. Regarding whether managerial efficiency is possible through effective communication, a slight higher number of respondents $(33.3 \%)$ disagreed while only $24.4 \%$ agreed.

\subsection{Descriptive Statistics on Business Trust}

Table 2. Showing descriptive statistics on business trust

\begin{tabular}{|c|c|c|c|c|c|c|}
\hline \multicolumn{2}{|l|}{ Statement } & 1 & 2 & 3 & 4 & 5 \\
\hline \multirow{2}{*}{ Trust in business is a great brand asset } & Frequency & 14 & 10 & 12 & 36 & 18 \\
\hline & $\%$ & 15.5 & 11.1 & 13.3 & 40.0 & 20.0 \\
\hline \multirow[t]{2}{*}{ Business trust facilitates improved customer loyalty } & Frequency & 7 & 18 & 9 & 36 & 20 \\
\hline & $\%$ & 7.8 & 20.0 & 10.0 & 40.0 & 22.2 \\
\hline \multirow{2}{*}{$\begin{array}{l}\text { Trust builds cordial relations between the business and } \\
\text { customers }\end{array}$} & Frequency & 16 & 10 & 12 & 34 & 18 \\
\hline & $\%$ & 17.8 & 11.1 & 13.3 & 37.8 & 20.0 \\
\hline \multirow{2}{*}{$\begin{array}{l}\text { Trust enables leaders or managers to stay committed } \\
\text { to their decisions }\end{array}$} & Frequency & 10 & 4 & 13 & 47 & 16 \\
\hline & $\%$ & 11.1 & 4.4 & 14.4 & 52.2 & 17.7 \\
\hline \multirow{2}{*}{$\begin{array}{l}\text { Employee morale and productivity increase with } \\
\text { higher trust in an organization }\end{array}$} & Frequency & 6 & 18 & 11 & 31 & 24 \\
\hline & $\%$ & 6.7 & 20.0 & 12.2 & 34.4 & 26.7 \\
\hline
\end{tabular}

Source: Survey (2021) 
Results in table 2 show that majority of the respondents (40\%) agreed that trust in business is a great brand asset and only $11.1 \%$ disagreed. Concerning whether business trust facilitates improved customer loyalty, majority of the respondents $(40 \%)$ agreed while the least number of respondents $(7.8 \%)$ strongly disagreed. This results clearly shows that high levels of trust in business play a key role in improving the general loyalty of customers. With respect to whether trust builds cordial relations between the business and customers, majority of the respondents (37.8\%) agreed and only $11.1 \%$ disagreed. In regard to whether trust enables leaders or managers to stay committed to their decisions, slightly more than a half of respondents (52.2\%) agreed and only $4.4 \%$ disagreed. Concerning whether employee morale and productivity increase with higher trust in an organization, majority of respondents (34.4\%) agreed and only $6.7 \%$ strongly disagreed.

\subsection{Descriptive Statistics on Business Growth}

Table 3. Showing descriptive results on business growth

\begin{tabular}{|c|c|c|c|c|c|c|}
\hline \multicolumn{2}{|l|}{ Statement } & 1 & 2 & 3 & 4 & 5 \\
\hline \multirow{2}{*}{$\begin{array}{l}\text { We have achieved greater profitability over the } \\
\text { last } \\
\text { one year }\end{array}$} & Frequency & 6 & 4 & 7 & 42 & 31 \\
\hline & $\%$ & 6.7 & 4.4 & 7.8 & 46.7 & 34.4 \\
\hline \multirow{2}{*}{$\begin{array}{l}\text { The business' Return on Assets is on a steady } \\
\text { progress }\end{array}$} & Frequency & 9 & 10 & 7 & 24 & 41 \\
\hline & $\%$ & 10.0 & 11.1 & 7.8 & 26.7 & 45.6 \\
\hline \multirow{2}{*}{$\begin{array}{l}\text { Return on Equity has greatly progress over the } \\
\text { least one year }\end{array}$} & Frequency & 6 & 9 & 10 & 36 & 29 \\
\hline & $\%$ & 6.7 & 10.0 & 11.1 & 40.0 & 32.2 \\
\hline \multirow[t]{2}{*}{ There is increase in sales in our business } & Frequency & 0 & 0 & 19 & 51 & 20 \\
\hline & $\%$ & 0 & 0 & 21.1 & 56.7 & 22.2 \\
\hline \multirow{2}{*}{$\begin{array}{l}\text { Customer loyalty and customer base are on } \\
\text { increase in the company }\end{array}$} & Frequency & 12 & 18 & 11 & 34 & 15 \\
\hline & $\%$ & 13.3 & 20.0 & 12.2 & 37.8 & 16.7 \\
\hline
\end{tabular}

Source: Survey (2021)

The results in table 3 show that majority of the respondents $(46.7 \%)$ agreed that their businesses had achieved greater profitability over the last one year while only $4.4 \%$ disagreed. This was a clear manifestation that the utilization of business communication tools and encouraging business trust, greatly enhances the profitability levels of that a particular venture or business. Regarding whether the business' Return on Assets is on a steady progress, a slightly higher number if respondents $(26.7 \%)$ agreed while only $11.1 \%$ disagreed. Concerning whether Return on Equity has greatly progress over the least one year a great number if respondents $(40 \%)$ agreed while only $6.7 \%$ strongly disagreed. Concerning whether there is increase in sales in the business, more than half of the respondents $(56.7 \%)$ agreed and only $21.1 \%$ were undecided. Concerning whether the Customer loyalty and customer base are on increase within the company, a slight majority of respondents (37.8\%) agreed and only $20 \%$ of respondents disagreed. This result clearly indicated that embracing business trust and consequently utilizing the different challenges of business communication helps to uplift the company's customer base and loyalty. These two aspects are so essential towards continued business growth.

\subsection{Correlation Analysis}

To establish the effects of business communication and business trust on business growth, correlation analysis was done and the results are presented in table 4.

Table 4. Showing results of correlation analysis

\begin{tabular}{|l|l|l|l|}
\hline & Business communication & Business trust & Business growth \\
\hline Business communication & 1 & & \\
\hline Business trust & $0.751^{* *}$ & 1 & \\
\hline
\end{tabular}




\begin{tabular}{|l|l|l|l|}
\hline & 0.00 & & \\
\hline Business growth & $.658^{*}$ & $0.719^{*}$ & 1 \\
\hline & 0.00 & 0.001 & \\
\hline
\end{tabular}

**Correlation is significant at the 0.01 level (1-tailed)

The results in table 6 show a positive correlation between business communication $(r=0.658)$ and is significant at 0.01 . This shows that the different forms of business communication including vertical, horizontal or downward communication, have a great impact on the growth of a business. The results also showed a positive correlation between business trust and business growth $(r=0.905)$ is this was significant at 0.01 . This was a clear indication that establishing trust in business most especially with customers, helps to enhance the profitability or sales volumes, leading to business growth.

\subsection{Multiple regression analysis}

Regression analysis was also conducted to establish the level to which business growth is predicted by business communication and business trust and the results are presented in table 5.

Table 5. Showing results of regression analysis

\begin{tabular}{|l|l|l|l|l|l|l|l|}
\hline Model & \multicolumn{2}{|l|}{$\begin{array}{l}\text { Unstandardized } \\
\text { Coefficients }\end{array}$} & $\begin{array}{l}\text { Standardized } \\
\text { Coefficients }\end{array}$ & T & Sig. & R2 & $\begin{array}{l}\text { Adjusted } \\
\text { R2 }\end{array}$ \\
\hline & B & Std. Error & Beta & & & & \\
\hline (Constant) & .318 & .136 & & 2.338 & .000 & .794 & .782 \\
\hline $\begin{array}{l}\text { Business } \\
\text { communication }\end{array}$ & .218 & .057 & .317 & 3.836 & .000 & & \\
\hline Business trust & .276 & .067 & .234 & 4.095 & .000 & & \\
\hline $\begin{array}{l}\text { Dependent Variable: Business growth } \\
\text { Predictors :Business communication, Business trust }\end{array}$ & & & & \\
\hline
\end{tabular}

Source: Survey (2021)

From table 5, the adjusted square of the multiple $\mathrm{R}$ was 0.782 indicating that the $78.2 \%$ of variance in business growth is jointly explained by the two independent namely business communication and business trust. Furthermore, the beta coefficient $\left(\beta_{1}\right)$ was 0.317 ; the p-value $(0.000)$ was less than the significance level (0.01). We accept the first hypothesis that, "there is a significant relationship between business communication and business growth." The beta coefficient $\left(\beta_{2}\right)$ was 0.234 ; the $\mathrm{p}$ value $(0.000)$ was less than the significance level (0.01). We therefore conclude that, "there is a significant relationship between business trust and business growth".

\section{Discussion}

The findings clearly show that business trust and business communication have a great influence in the growth of businesses. The correlation and regression results confirm a significant and positive relationship between the study variables. These findings are in line with findings of most scholars who have continuously connected effective communication and trust, with business growth (Hakanen et al., 2016; Kalogiannidis, 2020; Mohd Yusuf, 2012). Scolars have continued to argue that utilization of both effective communication and business trust influences customer loyalty and employee motivation and eventually leads to business growth. Many scholars view communication as a management function(Kalogiannidis \& Papaevangelou, 2020). This is absolutely true as proper management can only be carried out through effective communication. Communication has therefore been defined as a process of creating and passing ideas, opinions, facts and feelings from one person to the other, either within or without the organization(Yung, 2018). It has been confirmed that it is only through effective communication that everyone in an organization can know the overall objectives and goals to be achieved. From the literature, it is also evident that effective communication, trust and business ethics are important for business growth hence must always be adhered to by any business(Zeffane et al., 2011). 
The findings of this research show that business trust and communication are critical in the development of corporate business growth in the Greek business sector. Business growth is most influenced by communication(Zeffane et al., 2011). As a result, dealers in personal computers must focus on developing strategies and processes that guarantee that the goods or services provided meet or surpass client expectations (Hakanen et al., 2016). In order to accomplish corporate goals and objectives, a company dealing in personal computers must devote a significant amount of resources to meeting consumer demands. Satisfaction breeds loyalty, which is essential for a supplier to maintain a competitive edge (Gusev et al., 2020). Customers that are loyal to a company make it more lucrative. They increase the goodwill and reputation of a company via word of mouth. Customer satisfaction leads to long-term partnerships and a lower likelihood of relationship termination. As a result, a personal computers company must be able to establish trust, have efficient communication strategies, and please its consumers in order to solidify its market position, retain customers, and grow more lucrative (Gusev et al., 2020). A firm dealing in personal computers will be able to attract loyal clients by doing so. These clients will be willing to collaborate, to stay in a long-term relationship, and to propagate good word of mouth, all of which will assist to boost the firm's market reputation. Dealers in personal computers in Greece must be able to provide more trusted service to their consumers in order to look more effective, satisfying, and trustworthy.

One of the study's key limitations is that it utilized a judgmental sample, therefore the findings could only be regarded as representing the whole population of responders. This restricts the conclusions' generalizability, especially in terms of their relevance to other Greek industries. As a result, it is suggested that this research be reproduced in other Greek businesses.

\section{Conclusion and Recommendation}

In conclusion, it is evident that both effective communication and business trust leads to business growth. It is therefore important for a business to ensure that it puts in place measures that can enhance effective communication and business trust. Through these two aspects, the business would be able to achieve its set objectives and goals. It is therefore important for companies or businesses to embrace the different modern forms of communication and consequently promote trust in order to achieve desired levels of business growth. The exploration of the relationship between business trust and business communication on business growth in the Greek business sector is an important addition to the literature in the topic. In the topic of relationship marketing, this research contributes both theoretically and practically. Marketing managers, for example, would benefit from knowing that contentment is a crucial result of trust and communication between personal computer dealers and manufacturers.

\section{References:}

[1] Albert Bandura. (1999). Social cognitive theory. Asian Journal of Social Psychology, 21-41.

[2] A. S. Gusev, O. I. Betin, E. A. Skvortsov, N. V. Ziablitckaia, N. V. Vashukevich, Y. V. Malkova, The Analysis of Factors and Motivative Aspects Promoting and Hindering the Implementation of Precision Farming Technologies, pp. 820-830, WSEAS Transactions on Environment and Development, Volume 16, 2020

[3] Godlovitch, I., Monti, A., Schäfer, R. G., \& Stumpf, U. (2013). Business communications , economic growth and the competitive challenge. January, 104. http://www.wik.org/uploads/media/Final_Report _BusinessCustomers.pdf

[4] Hakanen, M., Kossou, L., \& Takala, T. (2016). Building Interpersonal Trust in Business Networks : Enablers and Roadblocks. Journal of Business Models, 4(1), 45-62. https://doi.org/10.5278/ojs.jbm.v4i1.1198

[5] Kalogiannidis, S. (2020). Impact of Effective Business Communication on Employee Performance. EJBMR, European Journal of Business and Management Research, 5(6). https://doi.org/http://dx.doi.org/10.24018/ejbmr.2 020.5.6.631

[6] Kalogiannidis, S., \& Papaevangelou, O. (2020). Impact of Business Communication on the Performance of Adult Trainees. International Journal of Academic Research in Progressive Education and Development, 9(3), 213-222. https://doi.org/10.6007/ijarped/v9-i3/8154

[7] McLean, S. (2013). Business Communication for 
Success. Journal of Chemical Information and Modeling, 53(9), 1689-1699.

[8] Mohd Yusuf, B. N. (2012). Communications and Trust Is a Key Factor to Success in Virtual Teams Collaborations. International Journal of Business and Technopreneurship, 2(May), 389397.

[9] Mouzas, S., Henneberg, S., \& Naudé, P. (2007). Trust and reliance in business relationships. European Journal of Marketing, 41(9-10), 1016-1032.

https://doi.org/10.1108/03090560710773327

[10] Prochaska, J. O., \& Velicer, W. F. (1997). The transtheoretical model of health behavior change. American Journal of Health Promotion, 12(1), 38-48. https://doi.org/10.4278/0890-117112.1.38

[11] Radomska, J., Wołczek, P., Sołoducho-Pelc, L., \& Silva, S. (2019). The impact of trust on the approach to management-A case study of creative industries. Sustainability (Switzerland), 11(3), 1-16. https://doi.org/10.3390/su11030816

[12] SINHA, R. K. (2012). Are Effective Communication Helps Building Trust and Improving Performance of A Service Industry: A Literature Review and Theory Building. Paripex - Indian Journal of Research, 3(8), 1-3. https://doi.org/10.15373/22501991/august2014/6 7

[13] Takemura, M., \& Sulimowska-formowicz, M. (2019). Business communication and trust in business relationships from the perspective of Polish managers. January.

[14] Waylen, A. (2017). The importance of communication in dentistry. Dental Update, 44(8), 774-780. https://doi.org/10.12968/denu.2017.44.8.774

[15] Yegana Alikhanli, Granger Causality Analysis of Foreign Trade Impact on Economic Growth: Case of Azerbaijan, pp. 384-389, WSEAS Transactions on Environment and Development, Volume 16, 2020

[16] Yung, H. S. (2018). Business Communication with Corporate Social Responsibility. Business Communication Research and Practice, 1(2), 51-53. https://doi.org/10.22682/bcrp.2018.1.2.51

[17] Zeffane, R., A Tipu, S., \& Ryan, J. C. (2011). Communication, Commitment \& Trust: Exploring the Triad. International Journal of Business and Management, 6(6). https://doi.org/10.5539/ijbm.v6n6p77

\section{Creative Commons Attribution License 4.0} (Attribution 4.0 International, CC BY 4.0)

This article is published under the terms of the Creative Commons Attribution License 4.0 https://creativecommons.org/licenses/by/4.0/deed.en_ $\underline{\mathrm{US}}$ 